\title{
Habitat selection and conservation status of the endemic Ninox hawk-owl on Cebu, Philippines
}

\author{
P. GODFREY C. JAKOSALEM, NIGEL J. COLLAR and JENNIFER A. GILL
}

\section{Summary}

The largely deforested island of Cebu, Philippines, hosts a forest-dwelling hawk-owl identified in the literature as Ninox philippensis spilonota but which is in fact a Cebu island endemic species, soon to be named. To determine the current distribution and habitat requirements of this hawkowl, the five largest of 11 remaining forest patches on Cebu were surveyed between March and June 2011, involving 64 post-sunset 500-m walked transects with playback and habitat assessments. Radio-telemetry studies were also conducted on 10 owls but only for 3-5 days per owl as they removed the transmitters. A total of 52 owls were located across all five forests (at 16 sites two owls responded together to playback) but only the largest forest, Alcoy, contained enough transects for analyses of habitat in relation to owl distribution. Alcoy stands on steep-sided hills and some planting of exotic species occurs within it. Owls were detected in forest interior, forest edge and forest-plantation mix in Alcoy, and on ridges and in gullies despite lower tree densities and greater proximity to clearings in the gullies. However, parts of Alcoy experience strong winds, and owl occupancy decreased significantly with increasing wind speed. Home ranges for the 10 radio-tagged owls were estimated to cover $\sim$ IO ha, although given the short tracking periods this may be an underestimate. Suitable forest studied covers roughly 1,670 ha, with six unstudied forests totalling 250 ha, so assuming a pair every to ha would give a tentative global population estimate of $\sim 200$ pairs of Cebu Hawk-owls, and even fewer if home ranges are larger than estimated. This, coupled with continuing habitat degradation, triggers the IUCN Red List category 'Endangered'. Tree cavities suitable for nests may be limiting, and nest-box provision could be explored, provided this does not increase predator pressure on other rare species.

\section{Introduction}

Forest destruction in the Philippines has become so acute in recent decades, and endemism in the archipelago is so high, that the country now possesses a disproportionately large number of threatened species for its size. For example, it has almost exactly the same complement of threatened birds as India ( 14 'Critically Endangered' and 13 'Endangered' each, and 47 and 51 'Vulnerable' respectively, the great majority being forest-dwellers; BirdLife International 2011) but on a land surface an order of magnitude smaller $\left(320,000 \mathrm{~km}^{2}\right.$ vs 3.3 million $\left.\mathrm{km}^{2}\right)$.

Of all the islands in the Philippines, Cebu is most notorious for its level of deforestation. A landmark paper by Rabor (1959) suggested that all the island's forests and, with them, nine of its ten endemic bird taxa (two species and seven subspecies) had already disappeared by the middle of the last century. That this was not so took over three decades to establish (Magsalay et al. 1995), by which time the forest fragments Rabor failed to detect had further diminished in size, thereby greatly reducing the prospects of those surviving taxa that had been presumed extinct (Collar 1998). Today these fragments amount collectively to $<17 \mathrm{~km}^{2}$, some $0.3 \%$ of the island's total area $\left(4,933 \mathrm{~km}^{2}\right)$, but while five of the nine taxa presumed extinct are now known to persist in these fragments, the other four remain missing (Brooks et al. 1995, Paguntalan and Jakosalem 2008). 
Taxonomic revisions may, however, increase the complement of endemic forms that survive in these fragments. One such instance concerns the Cebu representative of the Philippine Hawk-owl Ninox philippensis. This widespread Philippine endemic forest-dwelling nocturnal species is generally regarded as comprising seven or eight subspecies (Dickinson et al. 1991, Olsen 1999, Dickinson 2003). However, three subspecies differ from the rest in having barred not streaked underparts and are considered to represent more than one species (Collar and Rasmussen 1998). Of these three, one, spilonota, occupies the islands of Sibuyan, Tablas, Cebu and Camiguin Sur and is itself divisible into more than one species, of which the Cebu form represents one on its own (Rasmussen et al. in press). The survival of the Cebu Ninox, known from a single specimen collected in 1888 (McGregor 1909-1910), was only confirmed in 1998, when birds were recorded in three forest patches (Gonzalez et al. 1999). Since then the owl has been found in five of the II forest patches known to persist on Cebu (Paguntalan 2009), but in such modest numbers that a targeted survey became an urgent priority as soon as it was apparent that the bird's taxonomic identity was likely to upgrade to species status.

The aims of this survey were to assess habitat use and home-range size of the Cebu Ninox during the breeding season (presumed, from evidence of other species, to span March to June), with a view to extrapolating a very crude population estimate for each forest fragment, making allowance for the availability of appropriate habitat. By this means, a preliminary IUCN conservation status might be adduced, in the expectation of species status being recognised, and further research planned to improve the knowledge and conservation status of the species.

Our five study sites (north to south) were those visited by Paguntalan (2009), being the largest of the II remaining forest patches (see Discussion for the other six), namely: (I) Tabunan Forest $\left(10^{\circ} 26^{\prime} \mathrm{N} 123^{\circ} 49^{\prime} \mathrm{E}\right)$, on steep slopes at $400-880 \mathrm{~m}$, covering some 180 ha albeit with only 1o ha of continuous canopy (the only 'primary' forest patch in Cebu); (2) Dalaguete Forest $\left(9^{\circ} 82^{\prime} \mathrm{N} 123^{\circ} 49^{\prime} \mathrm{E}\right.$ ), comprising three blocks on steep slopes at different elevations $(60-200 \mathrm{~m}, 300-500 \mathrm{~m}$ and $500-800 \mathrm{~m})$, total area 500 ha; (3) Boljoon Forest $\left(9^{\circ} 65^{\prime} \mathrm{N} 123^{\circ} 45^{\prime} \mathrm{E}\right)$, consisting of five fragments at 50-400 m elevation, total area 160 ha; (4) Argao (or Mt Lantoy) Forest $\left(9^{\circ} 54^{\prime} \mathrm{N} 123^{\circ} 32^{\prime} \mathrm{E}\right.$ ), $100-800 \mathrm{~m}$ in elevation and covering 60 ha; and (5) Alcoy Forest $\left(9^{\circ} 52^{\prime} \mathrm{N} 123^{\circ} 30^{\prime} \mathrm{E}\right), \mathrm{o}-960 \mathrm{~m}$ in elevation and covering $>1,600$ ha, although this includes plantations and scrub (the largest block of forest being 800 ha). Apart from Tabunan, all forest patches are secondary but hold various indigenous trees including Ficus, Syzygium and Buchanania, and are surrounded by open farmland occasionally dotted with small relict copses, sometimes with abutting and intercalating areas of plantation, including mahogany Swietenia, teak Tectona, yemane Gmelina and eucalyptus. Access through the forests was by pre-defined tracks, commonest along gullies.

\section{Methods}

Fieldwork was conducted by PGCJ and a team of assistants at five study sites on Cebu between 28 March and 16 June 2011 (with environmental data-gathering by assistants into July), and was divided up into three components: nocturnal transects to determine owl presence or absence, home-range assessments using radio-telemetry, and specific habitat assessments of owl foraging and roosting sites. Incidental and anecdotal data were also gathered on nest-sites and prey items.

\section{Owl detection transects}

The presence of owls was assessed in five different forests involving 64 transects (Alcoy 41, Dalaguete 8, Boljoon 6, Argao 5, Tabunan 4). Transects extended $500 \mathrm{~m}$ in length, remained at least $100 \mathrm{~m}$ apart, and followed established trails. Each transect was walked once soon after sunset with surveyors listening for owl calls; three calling stations were established on each transect (at o, 250 and $500 \mathrm{~m}$ ) at which owl calls were broadcast. Broadcasts consisted of two minutes of prerecorded calls of the Cebu Ninox (using an mp3 player with portable speakers), including the 
species's double call, several screeches and occasional chittering calls (Rasmussen et al. in press), followed by a two-minute listening period and finally a spotlight search of the station. In Alcoy Forest, each transect was resurveyed on the following night without playback, in order to confirm owl presence and absence (all owls were relocated and no new owls were identified on these second surveys). Transect locations were stratified to ensure coverage of sites in the forest interior $(>30 \mathrm{~m}$ from forest edge; 27 transects), forest edge $(<30 \mathrm{~m}$ of forest edge; 27 transects) and forest-plantation mix (forest with some planted fruit trees and commercial exotics; 1o transects). All five forests are on steep-sided hills, and trails tended be either in gullies or on ridges; thus transect locations were also stratified to cover ridges ( 36 transects) and gullies (28 transects).

\section{Radio-telemetry}

Between II April and II June 2011, Io hawk-owls were captured using mist-nets and playback, and each was fitted with a tail-mounted Pip Ag393 transmitter (mass 2.3 g, supplied by Biotrack Ltd). Although these tags have a lifespan of 10 weeks at 50 pulses per minute (Kenward 2004), the hawk-owls quickly removed them. Owing to the capture effort required and the rate of tag removal (eight were found discarded within one week of deployment), the pattern developed that individual owls were tagged consecutively and tracked repeatedly (for 3-5 days) until the tag was removed. All captured owls were measured and checked for a brood-patch. Nine owls were adults and four of these had brood-patches. These four were consistently smaller than the other five (wing 175-181 vs 184-190 mm, tail 91-99 vs 100-109 mm, mass $120-129$ vs $124-142 \mathrm{~g}$ ), and we assumed them to be female and the other five to be male (males of other bar-breasted taxa placed in Ninox philippensis are consistently longer-winged and -tailed than females; Rasmussen et al. in press). The juvenile bird was within the size range of females (wing $175 \mathrm{~mm}$, tail $96 \mathrm{~mm}$, mass $118 \mathrm{~g}$ ).

Radio-tagged owls were tracked every night from dusk (one hour after sunset) to dawn (two hours before sunrise), when they were deemed most likely to be active. Daytime tracking was also carried out to locate potential nest and roost sites, and to identify any diurnal activity. Locations of radio-tagged owls were assessed by triangulation (White and Garrott 1990) using three-element Yagi antennae and Sica $138 \mathrm{mHz}$ receivers (Biotrack Ltd) and handheld GPS. The field team worked on foot along forest trails, roads, gullies and ridges, using handheld radios to facilitate synchronised tracking and to remain in contact. The direction of each located signal (azimuth) was determined by compass, and triangulation of directional signals was obtained by five-minute intervals (Mazur et al. 1998, Forsman et al. 2005). Tagged individuals at each recorded location were classified as foraging (signals moving) or roosting (signals stationary for $>30$ minutes; mostly diurnal records).

\section{Habitat characteristics of owl locations}

Following each detection transect, forest structure was quantified either at the locations where owls were recorded or, for transects without owls, at the transect mid-point. The habitat characteristics of the foraging and roosting locations of radio-tagged individuals (and of three locations where roosting owls were disturbed in daylight) were also assessed. A circular plot of $10 \mathrm{~m}$ radius, centred either on the tree in which an owl was first seen or on the nearest tree to the transect midpoint, was established at each location; the circle was divided into four quadrants to facilitate counting, and the variables described in Table I (six for transect sites, the same six plus five others for radio-tracking sites) were recorded. Apart from mean tree height and density, we recorded maximum tree height and number of tall $(>6 \mathrm{~m})$ trees within each plot, assuming a correlation between increasing tree height and increasing probability of suitable nesting cavities. Local wardens suggested that wind, to which Alcoy Forest is subject in the north-west and south-east 
Table 1. Name, unit and description of each of the habitat characteristics recorded in survey plots $\left(314 \mathrm{~m}^{2}\right)$ on hawk-owl detection transects in five forests on Cebu Island, Philippines. The surveys in which each variable was recorded ( $\mathrm{T}=$ transect surveys, $\mathrm{R}=$ locations of radio-tracked individuals) are also shown.

\begin{tabular}{|c|c|c|c|}
\hline Variable & Unit & Survey & Description \\
\hline Maximum tree height & $\mathrm{m}$ & $\mathrm{T}, \mathrm{R}$ & $\begin{array}{l}\text { Visual estimate of height of tallest tree within } \\
\text { each plot }\end{array}$ \\
\hline Mean tree height & $\mathrm{m}$ & $\mathrm{T}, \mathrm{R}$ & Mean height of all trees taller than $3 \mathrm{~m}$ \\
\hline Number tall trees & number & $\mathrm{T}, \mathrm{R}$ & Number of trees taller than $6 \mathrm{~m}$ within each plot \\
\hline Total number trees & number & $\mathrm{T}, \mathrm{R}$ & Total number of trees taller than $3 \mathrm{~m}$ within each plot \\
\hline Distance to clearing & $\mathrm{m}$ & $\mathrm{T}, \mathrm{R}$ & $\begin{array}{l}\text { Estimate of distance of plot from nearest forest } \\
\text { clearing or farm }\end{array}$ \\
\hline Wind speed & $\mathrm{km} /$ hour & $\mathrm{T}, \mathrm{R}$ & $\begin{array}{l}\text { Wind speed measured with anemometer at } \\
\text { one location on each transect. }\end{array}$ \\
\hline Transect location & categorical & $\mathrm{R}$ & Ridge or gully \\
\hline No. perching branches & number & $\mathrm{R}$ & $\begin{array}{l}\text { Total number of branches suitable for owl perching } \\
(>2 \mathrm{~cm} \text { diameter }) \text { on trees taller than } 6 \mathrm{~m}\end{array}$ \\
\hline Canopy cover & $\%$ & $\mathrm{R}$ & $\%$ canopy cover measured with densiometer \\
\hline Mean DBH & $\mathrm{cm}$ & $\mathrm{R}$ & Diameter at breast height for all trees taller than $6 \mathrm{~m}$ \\
\hline Understorey cover & $\%$ & $\mathrm{R}$ & $\%$ cover of understorey vegetation ( $<1 \mathrm{~m}$ height $)$ \\
\hline
\end{tabular}

(particularly in mid-June to July and in November), may influence owl distribution; so each transect point was visited once with an anemometer in order to measure wind speed.

\section{Nest-site and dietary data}

For two nests found, the tree species and nest-hollow characteristics were recorded, along with estimates of canopy cover and height, understorey cover and slope in the immediate vicinity (circular plots of $10 \mathrm{~m}$ radius centred on the nest tree), plus estimates of habitat-patch size and distance to the main forest and nearest clearing or farmland.

During fieldwork, there were a few occasions when hawk-owls were observed carrying prey. The types of prey observed were collated, and forest wardens were interviewed about the prey they had seen hawk-owls carrying.

\section{Data analysis}

Differences in measures among the five forests were compared using a Kruskal-Wallis test. To explore differences in habitat structure and wind speed on transects with and without owls, a logistic regression was constructed which included maximum tree height, number of tall trees, distance to nearest clearing, location (ridge or gully) and wind speed (Table 1). Only transects in Alcoy Forest were included in this model because the size of the other sites allowed too few transects. Collinearity between predictor variables was checked prior to analysis, and location (ridge or gully) was a categorical predictor. In Alcoy Forest, differences in forest structure and wind speed between transects on ridges and gullies were compared with t-tests.

Estimates of home range size of tracked individuals were made using ArcView GIS version 3.2a with the Animal Movement Extension (Hooge and Eichenlaub 2000). We estimated home range using $95 \%$ minimum convex polygons (MCP) and kernels from $50 \%$ and $95 \%$ probability models, as the latter are less prone to outlier effects (Worton 1989, Mazur et al. 1998, Forsman et al. 2005). One location from each triangulation fix was included in the home range estimates. The sizes of home ranges (a) that did and did not encompass forest edges, and (b) of male and female owls, were compared with Mann-Whitney U-tests. 


\section{Results}

\section{Habitat preferences from detection transects}

Hawk-owls were detected on 22/41 transects in Alcoy, 2/8 in Dalaguete, 3/6 in Boljoon Forest, $3 / 5$ in Argao and 4/4 in Tabunan, hence in all five forest sites surveyed on Cebu (Figure 1). Across the five forests, a total of 52 owls were detected in forest interior, forest edge and forest-plantation mix (Table 2). At 16 locations, two owls responded to playback together, suggesting that there were at least 16 pairs of owls within the total.

The five forests were similar in mean tree height $\left(X^{2}{ }_{4}=5.6, P<0.23\right)$, total numbers of trees $\left(\mathrm{X}_{4}^{2}=5.8, P<0.21\right)$ and number of tall trees $\left(\mathrm{X}_{4}^{2}=9.2, P<0.06\right)$ recorded on the transect surveys, but maximum tree heights were significantly greater in Alcoy (mean $10.2 \pm 0.44 \mathrm{SE}$ ) and Tabunan (12.5 \pm 1.55$)$ than in Dalaguete $(8.5 \pm 0.26)$, Boljoon (7.0 \pm 0.86) or Argao $(9.4 \pm 1.02)\left(X_{4}^{2}=11.3, P<0.03\right)$. Transects in the five forests did not differ significantly in distance from clearings and farms $\left(\mathrm{X}_{4}^{2}=2.8, P<0.59\right)$, although some larger distances were recorded in Alcoy reflecting the larger area of continuous forest here.

Logistic regression analysis of the factors suspected of affecting presence and absence of owls on transects in Alcoy showed that only wind speed was statistically significant (Wald $=11.71, \mathrm{df}=1$, $P<0.001$ ), with the probability of owl occupancy declining significantly with increasing wind

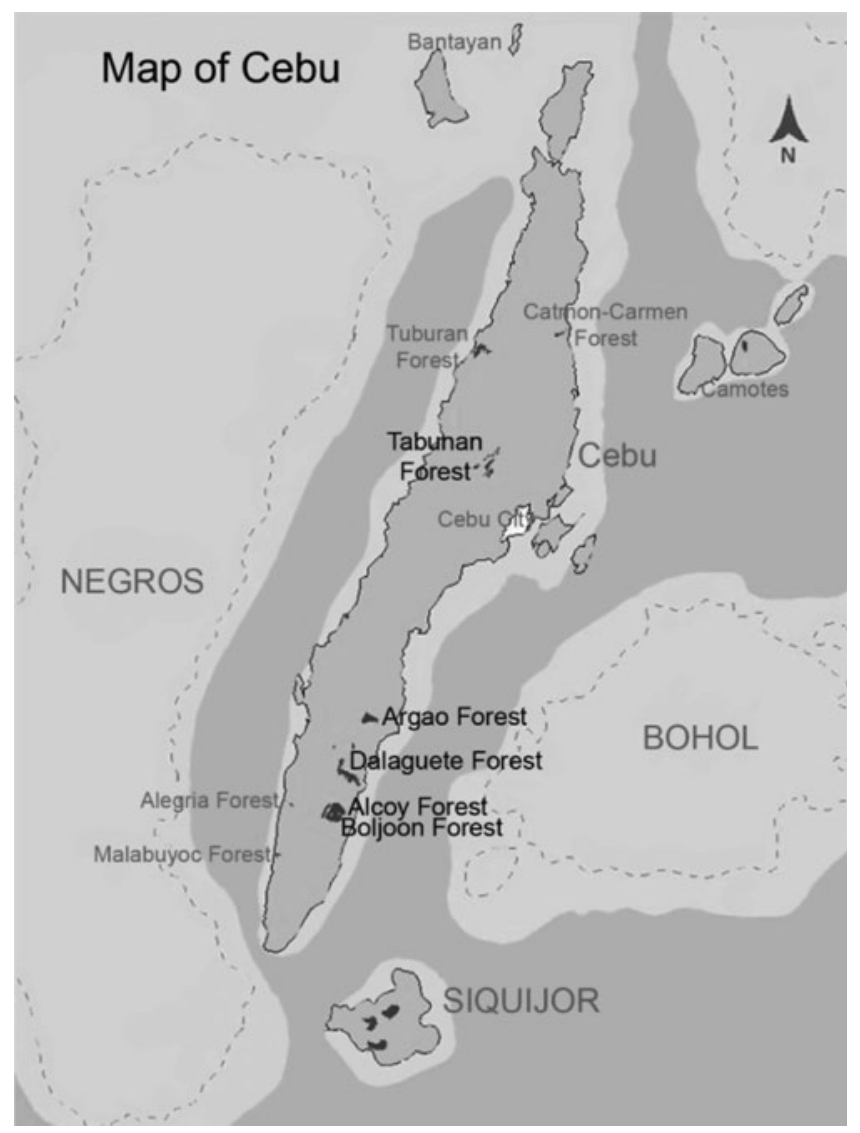

Figure 1 . Location of the five surveyed forests (in bold) within Cebu Island, Philippines. 
Table 2. The total number of hawk-owls and the estimated number of pairs recorded on transects through different habitats in five forest on Cebu Island (see text for details).

\begin{tabular}{|c|c|c|c|c|c|c|c|c|c|c|}
\hline \multirow[t]{2}{*}{ Habitat } & \multicolumn{2}{|c|}{ Alcoy } & \multicolumn{2}{|c|}{ Dalaguete } & \multicolumn{2}{|c|}{ Boljoon } & \multicolumn{2}{|c|}{ Argao } & \multicolumn{2}{|c|}{ Tabunan } \\
\hline & $\begin{array}{l}\text { No. } \\
\text { owls }\end{array}$ & $\begin{array}{l}\text { No. } \\
\text { pairs }\end{array}$ & $\begin{array}{l}\text { No. } \\
\text { owls }\end{array}$ & $\begin{array}{l}\text { No. } \\
\text { pairs }\end{array}$ & $\begin{array}{l}\text { No. } \\
\text { owls }\end{array}$ & $\begin{array}{l}\text { No. } \\
\text { pairs }\end{array}$ & $\begin{array}{l}\text { No. } \\
\text { owls }\end{array}$ & $\begin{array}{l}\text { No. } \\
\text { pairs }\end{array}$ & $\begin{array}{l}\text { No. } \\
\text { owls }\end{array}$ & $\begin{array}{l}\text { No. } \\
\text { pairs }\end{array}$ \\
\hline Forest interior & 20 & 9 & o & o & o & o & o & $\mathrm{O}$ & 2 & 1 \\
\hline Forest edge & 7 & 2 & 1 & o & 1 & o & 1 & $\mathrm{O}$ & 2 & o \\
\hline $\begin{array}{l}\text { Forest- plantation } \\
\text { mix }\end{array}$ & 10 & 2 & 2 & 1 & 2 & o & 3 & 1 & 1 & o \\
\hline Total & 37 & 13 & 3 & 1 & 3 & o & 4 & 1 & 5 & 1 \\
\hline
\end{tabular}

speed (Figure 2). Wind speed correctly predicted $84.2 \%$ of the 19 transects without owls and $90.9 \%$ of the 22 transects with owls within the logistic regression model, with owls being very rarely recorded on transects on which wind speed readings exceeded $2 \mathrm{~km} / \mathrm{hr}$ (Figure 2). These sites were typically on the western and eastern edges of the forest, which during monsoons can experience wind speeds of $\sim 30 \mathrm{~km} / \mathrm{hr}$ (PGCJ pers. obs.).

Within Alcoy, owls were located on both ridges (10/22 transects) and gullies ( $12 / 19$ transects). Mean tree height and total number of trees within survey plots was significantly greater on ridges (height: $13.8 \mathrm{~m} \pm$ 1.0 SE; number: 43.1 trees \pm 2.4 ) than gullies (10.6 m $\pm 3.5 ; 31.8 \pm 2.4$; height: $t_{41}=2.55, P<0.015$; number: $t_{41}=3.3, P<0.002$ ), possibly owing to higher levels of forest exploitation in gullies, and ridge plots were significantly further from clearings and farms (gully mean: $74.2 \mathrm{~m} \pm 28.9$; ridge: $190.9 \mathrm{~m} \pm 39.3, t_{41}=2.32, P<0.025$ ). However, in general forest structure on ridges and in gullies was very similar.

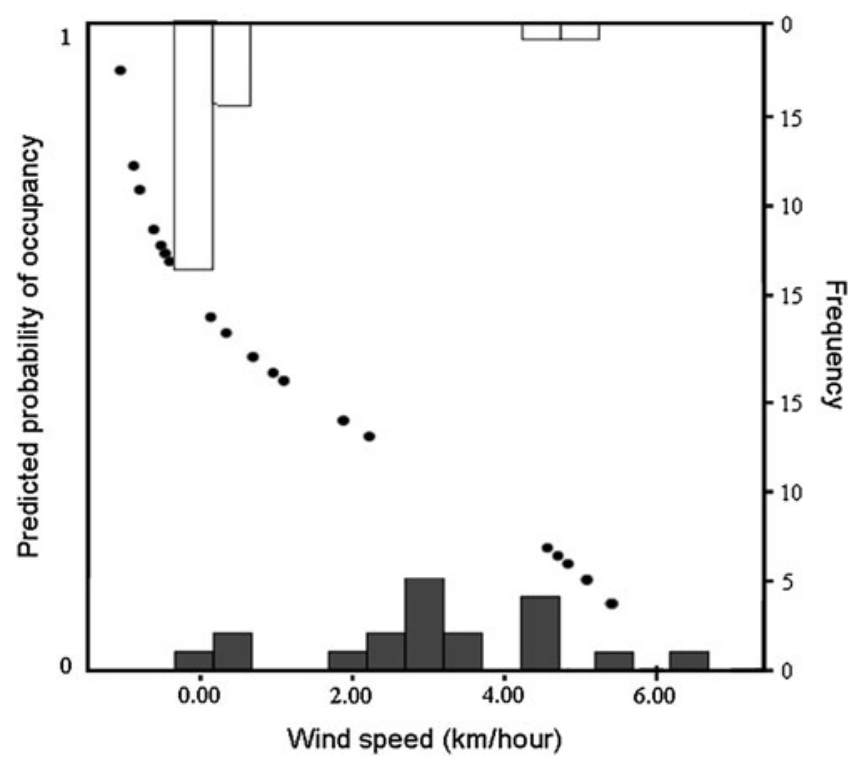

Figure 2. The effect of wind-speed on the probability (dotted curve) of occupancy of hawk-owls on transects in Alcoy Forest, Cebu Island, predicted from a logistic regression model. Wind speeds recorded on occupied (open bars) and unoccupied (filled bars) transects are shown, together with their frequencies. 


\section{Home range size and habitat use from radio-telemetry}

Five males, four females and one juvenile hawk-owl were each radio-tracked for $3-5$ days, between April and June 2011 (Table 3 ). On average, 120 fixes ( \pm 75.2 SD) were obtained per bird. These 10 individuals occupied both the interior and edge of forest, and their mean home range size was between 7.24 ha \pm 4.1 SD (95\% MCP) and 8.31 ha $\pm 4.19 \mathrm{SD}(95 \%$ kernel), while the mean from the $50 \%$ kernel estimate was 2.67 ha $\pm 1.34 \mathrm{SD}$ (Table 3). There was no significant difference between home range size of males and females ( $95 \% \mathrm{MCP}: \mathrm{U}_{4,6}=6.5, \mathrm{P}=0.24 ; 95 \%$ kernel: $\mathrm{U}_{4,6}=8.0, \mathrm{P}=0.39$ ); the largest home range size estimate was 12.98 ha (Table 3 ). The juvenile had a relatively small home range, although not the smallest (Table 3 ). Home range sizes in forest interior and forest edge were not significantly different ( $95 \% \mathrm{MCP}: \mathrm{U}_{4,5}=6.5, P=0.38 ; 95 \%$ kernel: $\mathrm{U}_{4,5}=8.0, P=0.62$ ), although forest edge birds were observed moving between adjacent forest patches.

The home ranges of the four females and two of the males were within the main forest area (Figure 3). One female made occasional use of the industrial tree plantation for foraging and one male was observed in a small forest patch inside scrub. There are several small forest patches to the west of the main forest, and the home ranges of one male and the juvenile were in forest patches and adjacent farmland (Figure 3), but foraging within farmland was only observed in one owl on one occasion, $<$ 1o $\mathrm{m}$ from the forest edge. None of the home ranges of the 1o radio-tracked owls overlapped (Figure 3).

\section{Roosting and foraging sites}

Hawk-owls were radio-tracked on their nocturnal foraging trips and at diurnal roosting locations. The habitat characteristics of foraging and roosting locations were similar: tall trees were always

Table 3. Estimates of home range size (from 95\% MCP, 95\% kernel and 50\% kernel home range analyses) of adult male and female and juvenile hawk-owls radio-tracked within Alcoy Forest, Cebu Island. Names in italic indicate those with home ranges in the forest interior, and mean home range sizes for forest interior and forest edge are given.

\begin{tabular}{|c|c|c|c|c|c|c|}
\hline Owl & Tracking period & $\begin{array}{l}\text { Tracking } \\
\text { days }\end{array}$ & $\begin{array}{l}\text { Radio } \\
\text { fixes (n) }\end{array}$ & $\begin{array}{l}95 \% \text { MCP } \\
\text { (ha) }\end{array}$ & $\begin{array}{l}95 \% \text { kernel } \\
\text { (ha) }\end{array}$ & $\begin{array}{l}50 \% \\
\text { kernel (ha) }\end{array}$ \\
\hline \multicolumn{7}{|l|}{ Adult males } \\
\hline Ryan & 8-11 May 2011 & 4 & 207 & $7 \cdot 95$ & 8.43 & 2.71 \\
\hline Godo & 3-7 May 2011 & 5 & 140 & $4 \cdot 54$ & 5.67 & 3.23 \\
\hline Lisa & $1-3$ June 2011 & 3 & 54 & 1.13 & 1.59 & .089 \\
\hline Doro & 11-12 April 2011 & 3 & 31 & 5.29 & 9.45 & 5.09 \\
\hline Tito & $22-25$ May 2011 & 5 & 131 & 11.91 & 12.49 & 3.11 \\
\hline Mean \pm SD & & & & $6.2 \pm 4.0$ & $7.52 \pm 4.1$ & $3.0 \pm 1.5$ \\
\hline \multicolumn{7}{|l|}{ Adult females } \\
\hline Orlyn & 11-14 May 2011 & 4 & 94 & 9.63 & 11.43 & 3.55 \\
\hline Elline & 25-27 May 2011 & 3 & 53 & 10.63 & 12.87 & 3.25 \\
\hline Pedro & 19-21 May 2011 & 3 & 64 & 12.62 & 12.98 & 2.44 \\
\hline Sidro & 20-23 May 2011 & 4 & 163 & $5 \cdot 58$ & $5 \cdot 98$ & 1.65 \\
\hline Mean \pm SD & & & & $9.61 \pm 3.0$ & $10.81 \pm 3.3$ & $2.72 \pm 0.8$ \\
\hline \multicolumn{7}{|l|}{ Juvenile } \\
\hline James & 26-30 April 2011 & 5 & 263 & 2.14 & 2.89 & 1.63 \\
\hline $\begin{array}{l}\text { Overall } \\
\quad \text { mean } \pm \mathrm{SD}\end{array}$ & & & & $7.04 \pm 4.0$ & $8.37 \pm 4.2$ & $2.75 \pm 1.2$ \\
\hline $\begin{array}{r}\text { Forest Interior } \\
\text { mean } \pm \mathrm{SD}\end{array}$ & & $3.83 \pm 1.0$ & 107.66 & $5.89 \pm 4.4$ & $7 \cdot 33 \pm 4 \cdot 3$ & $2.80 \pm 1.5$ \\
\hline $\begin{array}{l}\text { Forest Edge } \\
\text { mean } \pm \mathrm{SD}\end{array}$ & & $4.0 \pm 0.8$ & $138.5 \pm 64.9$ & $9.01 \pm 2.8$ & $9.94 \pm 2.7$ & $0.72 \pm 0.07$ \\
\hline
\end{tabular}




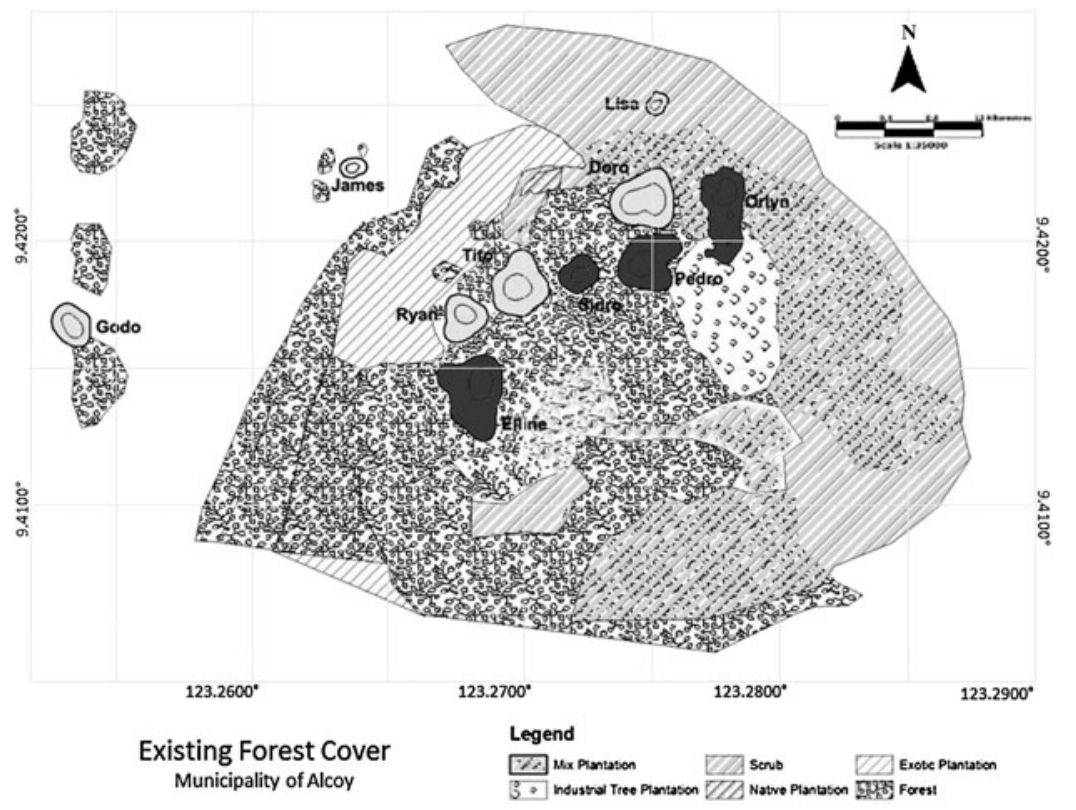

Figure 3. Home ranges of four adult female (dark grey), five adult male (pale grey) and one juvenile (white) radio-tagged hawk-owls in Alcoy Forest, Cebu Island (see Table 3 for details). Inner lines indicate $50 \%$ and outer lines indicate $95 \%$ kernel estimates of home ranges. The area of scrub contains some patches of regenerating forest.

present (foraging sites: mean 12.1 tall trees \pm 0.9 SE, roosting sites: $11.6 \pm 0.7$ ), with at least $25 \%$ understorey cover (foraging: $62.1 \% \pm 3.5$, roosting: $53.8 \% \pm 5.5$ ), and an abundance of potential perching branches (foraging: 732 branches \pm 147 , roosting: $732 \pm 108$ ). Of 13 roosting locations, seven were within the forest interior, three in forest edge, two in the forest-plantation mix and one in an exotic plantation, and roosting trees were typically covered with thick foliage (vines, leaves and epiphytes). Similarly, foraging locations were identified in both forest interior and forest edge, sometimes close to clearings (minimum distance $3 \mathrm{~m}$ from clearing). All foraging and roosting locations were in areas where wind speeds were very low $(<0.2 \mathrm{~km} /$ hour$)$.

\section{Nest sites and diet}

The two nest sites examined were both located in Alcoy Forest, below $700 \mathrm{~m}$ elevation, extremely close to farmland clearings in small patches of forest where people gather firewood. Both nests were in naturally formed cavities of similar dimensions $(\sim 10 \times 20 \mathrm{~cm})$ within the main trunk of tall trees ( $13 \mathrm{~m}$ and $20 \mathrm{~m}$ height) $\sim 2-2.5 \mathrm{~m}$ from the ground. The active nest, found on 4 May 2011 when two eggs were present (it was empty, conceivably having fledged young, when next inspected on 28 May), was in a live Melanolepis multiglandulosa, which is a native pioneer tree species with relatively soft wood, and was within an area of secondary plantation. The inactive nest, in which a recently hatched juvenile was observed in 2005 but which was inactive in 2011, was in a dead standing Vitex parviflora tree, which is itself a threatened species (Oldfield et al. 1998) and is a harder wood than Melanolepis.

During fieldwork in 2011, prey items seen being carried by hawk-owls were one rat, one sunbird, one cicada and two crickets. Wardens at Alcoy reported seeing hawk-owls carrying a variety of prey types, including rats, small birds (sunbirds, flowerpeckers, titmice and flycatchers), colubrid snakes, agamid lizards, skinks, geckos, frogs, toads, cicadas, mantises, moths, stick insects and crickets. 


\section{Discussion}

The Cebu Hawk-owl appears to occupy forest of various types, with no obvious preference for interior or edge, gully or ridge, patch size or canopy height, although it was only occasionally recorded in areas of pure plantation. Owl foraging and roosting locations in Alcoy Forest were similar in structure, and spanned forest interior and edge, sometimes close to clearings and farms. This is encouraging, but little forest remains on Cebu, and it would be unwise to assume that the species fares equally well in all habitat types.

The one significant constraint on owl occupation of forest appeared to be wind. In Tasmania moderate to strong winds significantly decrease the detectability of Australian Masked Owl Tyto novaehollandiae and Southern Boobook (Morepork) Ninox novaeseelandiae (Bell and Mooney 2002), but in Cebu wind can apparently exclude birds altogether (none was detected in windaffected areas during calm weather, suggesting this was not a matter of detectability). We speculate that acoustic effects wrought by wind among branches and leaves may interfere with the owls' ability to detect prey and each other's signals.

Absence from wind-affected forest, if real, will constrain the global population size. Table 3 suggests that a breeding pair of Cebu Hawk-owls occupies around to ha of forest (possibly larger if the areas each sex uses are not fully coincidental). The total area of forest investigated in this study was 2,500 ha (Tabunan 180 ha, Dalaguete 500 ha, Boljoon 160 ha, Argao 60 ha and Alcoy 1,60o ha), but 500 ha of Alcoy is unsuitable pure plantation and some $30 \%$ of the rest ( 330 ha) is affected by wind (PGCJ pers. obs.), so suitable forest at Alcoy is $\sim 770$ ha. This leaves 1,670 ha of habitat, enough for 167 pairs of hawk-owls. However, six forest patches on Cebu remain unsurveyed: Alegria (3o ha), Badjan (3o ha), Carmen (6o ha), Catmon (6o ha), Malabuyoc (2o ha) and Tuburan (reportedly 420 ha but mostly industrial tree plantation; here assumed to hold 50 ha of forest at maximum). These areas add up to 250 ha, and so may hold another 25 hawk-owl pairs. By this crude calculation the global total of Cebu Hawk-owls might be $<200$ pairs. However, as the period of time between tagging and loss of transmitter was only 3-5 days, the birds sampled may not have covered all the area of their home ranges, especially if they were staying close to a nest, and the values in Table 3 may be underestimates (although they are similar to another small forest-dwelling owl; Virani 2010). If instead a pair typically occupies $15^{-20}$ ha, the global population estimate would reduce to some 100-130 pairs.

However, the habitat of a home range or territory need not be continuous. Small forest patches of $1-2$ ha surrounded by farmland and/or exotic plantations (but close to larger forest blocks) are used by the species, as revealed by three radio-tagged owls that were recorded from such patches. More probably it is nest-site availability that is crucial for the species, as with other owl populations (Newton 1994, Taylor et al. 2002, Cockle et al. 2010). Natural cavities form in trees of a certain age and size, and in this regard the (albeit small) forest at Tabunan, which holds the most mature trees on Cebu, may support higher numbers of owls than the island's other (all secondary) forests, in which the trees are relatively young. Moreover, plantations commonly involve species of tree that are felled too young to (or naturally never) form cavities. Experiments in different habitats with nest-boxes and prey-sampling equipment would elucidate key habitat components for the owl, but should proceed with caution since artificially increasing numbers of this seemingly generalist predator could affect populations of some other highly threatened taxa (most notably the Cebu Flowerpecker Dicaeum quadricolor).

Despite the legal protection of all natural forest in the Philippines and the further support that Alcoy, Argao, Dalaguete and Tabunan receive from local government units and communities (only Boljoon gets none), the expansion of agriculture and fuelwood gathering is creating increasing pressure on the last remaining forests on Cebu (Bensel 2008), with encroachment, timber-poaching and fuelwood gathering still rampant. If our crude estimates of population size (130-200 pairs; 260-400 mature individuals) are correct, the continuing erosion of the quality and perhaps extent of the fragmented forests in which the hawk-owl survives would seem to qualify the species for IUCN status 'Endangered' under Red List criteria B2ab(iii) and C2a(i). 


\section{Acknowledgements}

This project was funded by the Ford International Fellowship Program, Chester Zoo Studentship, World Owl Trust, Philippines Biodiversity Conservation Foundation, BirdLife International, Wetland Trust and University of East Anglia. Permits were granted by the Department of Environment and Natural Resources, municipalities of Alcoy, Dalaguete, Argao, Boljoon and community council of Tabunan and Nug-as, KMYLB people's organization in Nug-as and Cebu Biodiversity Conservation Foundation. We thank Reynaldo Yray (Protected Areas Wildlife and Coastal Zone Management Services), William L. R. Oliver, Lisa Marie Paguntalan, Orlyn Orlanes-Roxas, Kail Zingapan and Edgar Lillio for help and advice, and Teodoro Amaca, Tito Amaca, Fe Anore, Fernando Anore, Ryan Anore, Camilo Jakosalem, Jocam Jakosalem, Ara Patrice Kintanar, Bobby Kintanar, J. R. Margate, Meaffe Margate, Dexcem Pantinople, Sherry Paul Ramayla, Romele Sandot and Pedro Villarta for volunteer field assistance.

\section{References}

Bell, P. J. and Mooney, N. (2002) Distribution, habitat and abundance of Masked Owls (Tyto novaehollandiae) in Tasmania. Pp.120-132 in I. Newton, R. Kavanagh, J. Olsen and I. Taylor, eds. Ecology and conservation of owls. Victoria, Australia: CSIRO Publishing.

Bensel, T. (2008) Fuelwood, deforestation, and land degradation: 1o years of evidence from Cebu Province, the Philippines. Land Degradation \& Development 19: 587-605.

BirdLife International (2011) www.birdlife.org/ datazone/species. Accessed August 2011.

Brooks, T. M., Magsalay, P., Dutson, G. and Allen, R. (1995) Forest loss, extinctions and last hope for birds on Cebu. Oriental Bird Club Bull. 21: 24-27.

Cockle, K. L, Martin, K. and Drever, M. C. (2010) Supply of tree-holes limits nest density of cavity-nesting birds in primary and logged subtropical Atlantic forest. Biol. Conserv. 143: 2851-2857.

Collar, N. J. (1998) Extinction by assumption; or, the Romeo Error on Cebu. Oryx 32: 239-243.

Collar, N. J. and Rasmussen, P. C. (1998) Species limits in the Ninox philippensis complex. Ostrich 69: 398 (Proc. 22 Internatn. Orn. Congr.).

Dickinson, E. C., ed. (2003) The Howard \& Moore complete checklist of the birds of the world. Third edition. London: Christopher Helm.

Dickinson, E. C., Kennedy, R. S. and Parkes, K. C. (1991) The birds of the Philippines: an annotated check-list. Tring: British Ornithologists' Union (Check-list no. 12).
Forsman, E. D., Kaminske, T. J., Lewis, J. C., Maurice, K. J. and Sovern, S. G. (2005) Home range and habitat use of northern spotted owls on the Olympic Peninsula, Washington. J. Raptor Res. 39: 365-377.

Gonzalez, J. C., Dans, A. T. L., Pedregosa, M. G., Chiu, C. and Villahermosa, R. (1999) Island-wide survey of forest and fauna and flora inventory of selected sites for priority conservation on Cebu. Manila: Fauna \& Flora International (unpublished). Hooge, P. N. and Eichenlaub, B. (2000) Animal movement extension to ArcView. ver. 2.o. Anchorage: Alaska Science Center Biological Science Office, U.S. Geological Survey.

Kenward, R. E. (2004) Radio tagging. Pp.141-156 in W. J. Sutherland, I. Newton and R. E. Green, eds. Bird ecology and conservation: a handbook of techniques. Oxford: Oxford University Press.

Magsalay, P., Brooks, T., Dutson, G. and Timmins, R. (1995) Extinction and conservation on Cebu. Nature 373: 294.

Mazur, K. M., Frith, S. D. and James, P. C. (1998) Barred owl home range and habitat selection in the boreal forest of central Saskatchewan. Auk 115: 746-754.

McGregor, R. C. (1909-1910) A manual of Philippine birds. Manila: Bureau of Printing. Newton, I. (1994) The role of nest sites in limiting the numbers of hole-nesting birds: a review. Biol. Conserv. 70: 265-276.

Oldfield, S., Lusty, C. and MacKinven, A. (1998) The world list of threatened trees. Cambridge, UK: World Conservation Press. 
Olsen, P. D. (1999) Genus Ninox species accounts. Pp. 231-237 in J. del Hoyo, A. D. Elliott and J. Sargatal, eds. The Handbook of birds of the world, 5. Barcelona: Lynx Edicions.

Paguntalan, L. M. J. (2009) Cebu local forest conservation areas: assessment and action plan. Cebu, Philippines: Cebu Biodiversity Conservation Foundation, Inc. and Department and Environment and Natural Resources-VII.

Paguntalan, L. M. J. and Jakosalem, P. G. C. (2008) Significant records of birds in forests on Cebu island, central Philippines. Forktail 24: 48-56.

Rabor, D. S. (1959) The impact of deforestation on birds of Cebu, with new records for that island. Auk 76: 37-43.

Rasmussen, P. C., Allen, D. N. S., Collar, N. J., Demeulemeester, B., Hutchinson, R. O., Jakosalem, P. G. C., Kennedy, R. S.,
Lambert, F. R., \& Paguntalan, L. M. (in press) Vocal divergence and new species in the Philippine Hawk Owl Ninox philippensis complex. Forktail 28.

Taylor, I. R., Kirsten, I. and Peake, P. (2002) Habitat, breeding and conservation of the Barking Owl Ninox connivens in northeastern Victoria, Australia. Pp.116-124 in I. Newton, R. Kavanagh, J. Olsen and I. Taylor, eds. Ecology and conservation of owls. Victoria, Australia: CSIRO Publishing.

Virani, M. (2010) Home range and movement patterns of Sokoke Scops Owl Otus ireneae. Ostrich 71: 139-142.

White, G. C. and Garrott, R. A. (1990) Analysis of wildlife radio-tracking data. San Diego, CA: Academic Press,

Worton, B. J. (1989) Kernel methods for estimating the utilization distribution in home range studies. Ecology 70: 164-168.

\section{P. GODFREY C. JAKOSALEM}

School of Biological Sciences, University of East Anglia, Norwich Research Park, Norwich, NR4 ${ }_{7} T J$, UK, and Philippines Biodiversity Conservation Foundation, Inc. clo Negros Forest Ecological Foundation, Inc., South Capitol Road, Bacolod City 6oo1, Philippines.

NIGEL J. COLLAR

BirdLife International, Wellbrook Court, Girton Road, Cambridge CB3 oNA, UK.

JENNIFER A. GILL*

School of Biological Sciences, University of East Anglia, Norwich Research Park, Norwich, NR4 $7 T$, UK.

*Author for correspondence; email: j.gill@uea.ac.uk

Received 8 November 2011; revision accepted 9 April 2012; Published online 26 July 2012 